\title{
RANCANG BANGUN APLIKASI AKADEMIK BERBASIS JAVA PADA SMK PRESTASI PRIMA
}

\author{
Nadia Reforma ${ }^{1}$, Rizki Rizkyatul Basir ${ }^{2}$, Berta Dian Theodora ${ }^{3}$ \\ Program Studi Teknik Informatika, Fakultas Teknik dan Ilmu Komputer, \\ Universitas Indraprasta PGRI \\ Jalan Raya Tengah No 80, Kelurahan Gedong, Pasar Rebo, Jakarta Timur \\ nadiareforma58@gmail.com ${ }^{1}$, rizkyatulbasir@gmail.com ${ }^{2}$, berta.dtos@gmail.com ${ }^{3}$
}

\begin{abstract}
Abstrak
SMK Prestasi Prima sampai dengan tahun ajaran 2019/2020 belum sepenuhnya menggunakan pengolahan data secara komputerisasi dan menggunakan aplikasi, pengolahan data masih dilakukan secara manual kurang teroganisasi dengan baik sehingga data-data yang dikelola menjadi tidak konsisten, kurang lengkap dan akurat tidak serta belum efisien dan efektif. Tujuan penelitian untuk menggantikan sistem akademik pada SMK Prestasi Prima yang masih manual menjadi sistem yang terkomputerisasi. Metode penelitian aplikasi ini menggunakan metode deskriptif kualitatif yang menyajikan data berupa teks yang merinci dan teknik yang digunakan adalah metode kepustakaan. Hasil penelitian menunjukan bahwa aplikasi akademik berbasis java pada SMK Prestasi Prima dapat membantu pihak tata usaha menjadi lebih efektif dan efisien dalam bentuk biaya dan waktu dalam pengolahan data siswa dan guru, penjadwalan bagi guru dan proses pembuatan laporan.
\end{abstract}

Kata Kunci: Aplikasi, Akademik, Java, Sekolah Menengah Kejuruan

\begin{abstract}
SMK Prestasi Prima School up to the 2019/2020 school year has not fully used computerized data processing and uses applications, data processing is still done manually, it is not well organized so that the managed data becomes inconsistent, incomplete and accurate, not efficient and not yet efficient. effective. The purpose of this research is to replace the manual system at SMK Prestasi Prima which is still manual into a computerized system. This application research method uses a qualitative descriptive method that presents data in the form of detailed text and the technique used is the library method. The results showed that java-based academic applications at SMK Prestasi Prima can help the administration to be more effective and efficient in terms of cost and time in processing student and teacher data, scheduling for teachers and the reporting process.
\end{abstract}

Keywords: Application, Academic, Java, Vocational High School

\section{PENDAHULUAN}

Seiring dengan perkembangan teknologi pada era globalisasi ini, teknologi telah memberikan kemajuan dalam berbagai aspek, salah satunya adalah teknologi informasi. Teknologi informasi sangat membantu manusia dalam menyelesaikan pekerjaan dan kegiatan sehari-hari, meningkatkan efisensi serta memungkinkan melakukan pekerjaan dimana saja dan kapan saja. Adaptasi manusia dengan teknologi baru telah berkembang dan dilakukan melalui pendidikan. Bidang pendidikan memiliki kaitan erat dengan perkembangan teknologi dan informasi saat ini, dengan begitu teknologi dan pendidikan mampu berkembang bersama seiring dengan adanya generasi baru.

Sekolah sebagai suatu intansi di bidang pendidikan pastinya memerlukan sistem informasi dalam operasionalnya, seperti proses kegiatan belajar mengajar dan proses akademik lainnya akan menjadi lebih mudah dan cepat dengan adanya sistem yang terkomputerisasi sehingga akan memberikan hal positif dan manfaat untuk perkembangan sekolah. Pengolahan data yang dilakukan secara manual menyebabkan beberapa kendala dan permasalahan dalam pengolahan data seperti kurang akurat dalan pengolahannya, data-data tidak tersimpan dengan baik dan sering terjadi kesalahan saat proses pengolahan datanya. SMK Prestasi Prima saat ini belum sepenuhnya 
menggunakan sistem terkomputerisasi, sistem pengolahan data masih dilakukan secara manual sehingga data-data yang dikelola tidak teroganisir dengan baik, tidak efesien dan efektif.

Berdasarkan permasalahan tersebut, dibutuhkan sebuah sistem yang dapat menyelesaikan berbagai masalah yang ada agar dapat terorganisasi dengan baik. Sebuah sistem akan mampu membantu dalam pengolahan data siswa, data guru, data nilai siswa, data presensi dan data jadwal mengajar. Dengan permasalahan tersebut peneliti tertarik menulis jurnal dan melakukan penelitian di SMK Prestasi Prima dalam bidang akademik sekolah dengan judul "Rancang Bangun Aplikasi Akademik Berbasis Java pada SMK Prestasi Prima". Adapun tujuan dalam penelitian ini adalah memberikan gambaran secara umum kepada masyarakat tentang aplikasi akademik dan dapat berguna bagi pihak-pihak yang memerlukan referensi maupun sebagai bahan pembanding.

Perancangan adalah desain sistem menentukan bagaimana suatu sistem akan menyelesaikan yang mesti diselesaikan (Jogiyanto, 2010). Sistem merupakan suatu jaringan kerja dari prosedurprosedur yang saling berhubungan dan berkumpul bersama-sama untuk melakukan suatu kegiatan atau untuk melakukan sasaran yang tertentu (Jeperson, 2014). Informasi adalah data yang telah diklasifikasikan atau diolah dan diinterprestasikan untuk digunakan dalam proses mengambil keputusan (Sutabri, 2012). Sistem informasi merupakan suatu sistem dalam suatu organisasi yang mempertemukan kebutuhan pengolahan transaksi harian yang mendukung fungsi operasi organisasi yang bersifat manajerial dengan kegiatan strategi (Anggraeni \& Irviani, 2017). Aplikasi adalah program yang dibuat untuk melaksanakan tugas tertentu yang dibutuhkan oleh pengguna komputer (user) (Sugiarti, 2013). Netbeans merupakan sebuah aplikasi Integrated Development Environment (IDE) berbasis Java dari Sun Microsystems yang berjalan di atas swing (Ilham, 2019). Bahasa Pemrograman Java merupakan salah satu dari sekian banyak bahasa pemrograman yang dapat dijalankan di berbagai sistem operasi termasuk telepon genggam (Nofriadi, 2015).

\section{PENELITIAN RELEVAN}

Dalam rangka mendapatkan hasil penelitian yang baik, selain melakukan peneltian secara langsung penelitian juga melakukan kajian pustaka dari penelitian yang telah dilakukan sebelumnya, beberapa hasil penelitian yang menjadi acuan adalah penelitian dari (Kuryanti, 2014) dengan judul Web Dengan Java dengan hasil penelitian penerapan sistem absensi manual ke dalam sistem aplikasi dengan membuat database absensi agar dalam penerapan kedalam aplikasi lebih mudah karena setiap data sudah bisa diinput diaplikasinya begitupun dengan laporan.

Penelitian dari (Shiddiq \& Pradnya D, 2013) dengan judul Sistem Informasi Akademik dan Administrasi SDIT AR-Raihan Bantul dengan hasil penelitian dapat menghemat waktu untuk melakukan pencarian, pencatatan dan pemasukan data, dapat menghasilkan laporan dengan tepat dan cepat, dapat meningkatkan kinerja dalam rangka melakukan pelayanan dan menyelesaikan tugas-tugas dengan baik.

\section{METODE PENELITIAN}

Peneliti menggunakan metode penelitian Grounded Research dalam melakukan penelitian ini. Grounded Research yaitu suatu metode penelitian yang berdasarkan fakta yang menggunakan analisa perbandingan dengan maksud menetapkan konsep, generalisasi empiris, lalu mengembangkan teori, dalam waktu yang berdekatan mengumpulan dan menganalisis data untuk mendapatkan informasi yang diperlukan (Setiawan, Lina, \& Parwatiningtyas, 2020). Peneliti menggunakan desain penelitian dengan langkah-langkah yaitu menentukan masalah yang ingin di selidiki, mengumpulkan data, analisa dan penjelasan, membuat laporan hasil penelitian. Teknik penelitian yang digunakan peneliti pada penelitian ini antara lain melakukan wawancara (interview), penelitian pustakaan (library research) serta pengamatan (observation) dengan proses pengamatan dan penelitian langsung terhadap objek yang diteliti. Tahap pengembangan sistem antara lain dengan melakukan pengumpulan data yang dibutuhkan, dengan berfokus pada perangkat lunak meliputi informasi, fungsi masing-masing pada bagian sistem, kerja atau cara kerja dan antarmuka, melakukan perancangan sturktur data, struktur perangkat lunak, rincian prosedur dan karakteristik antarmuka, dibuat coding aplikasi sistem akademik yang merupakan tahap untuk 
membuat suatu kode tentang aplikasi yang akan dibuat, dilakukan pengujian terlebih dahulu, bagian akhir dari siklus pengembangan sistem laporan produksi dan tahap ini dilakukan setelah perangkat lunak dipergunakan.

\section{HASIL DAN PEMBAHASAN}

Berdasarkan masalah-masalah yang dihadapi berikut analisis proses yang diusulkan di SMK Prestasi Prima pada pengolahan data adalah sebagai berikut :

a. Proses Pendataan Siswa

Siswa memberikan data diri ke Tata Usaha, kemudian Tata Usaha menginput data kemudian disimpan ke dalam sistem sebagai data siswa.

b. Proses Pendataan Guru

Guru memberikan data diri setiap ada guru baru atau perubahan jabatan kepada Tata Usaha untuk di data sebagai guru yang mengajar di sekolah.

c. Proses Pendataan Mata Pelajaran

Tata Usaha membuat data jadwal mata pelajaran kemudian disimpan ke dalam sistem sebagai data mata pelajaran dan mencetak mata pelajaran yang diberikan kepada siswa dan masingmasing guru sebagai jadwal mengajar.

d. Proses Pendataan Kelas

Tata Usaha membuat data kelas dan mencetak data kelas yang tersedia pada SMK Prestasi Prima untuk mengetahui kuota dari kelas tersebut.

e. Proses Laporan

Tata Usaha mencetak semua data yang sudah diinput ke dalam sistem yang akan di berikan kepada Kepala Sekolah SMK Prestasi Prima Sebagai Laporan.

\section{Diagram Konteks yang Diusulkan}

Pada gambar diagram konteks yang diusulkan dibawah ini memperlihatkan secara umum dari sistem akademik pada SMK Prestasi Prima, yang menggambarkan sistem yang lebih terkomputerisasi. Tata Usaha yang dapat mengelola data siswa, data guru, data mata pelajaran dan data kelas. Selain itu tata usaha juga bertugas untuk mencetak laporan yang nantinya akan diberikan kepada Kepala Sekolah.

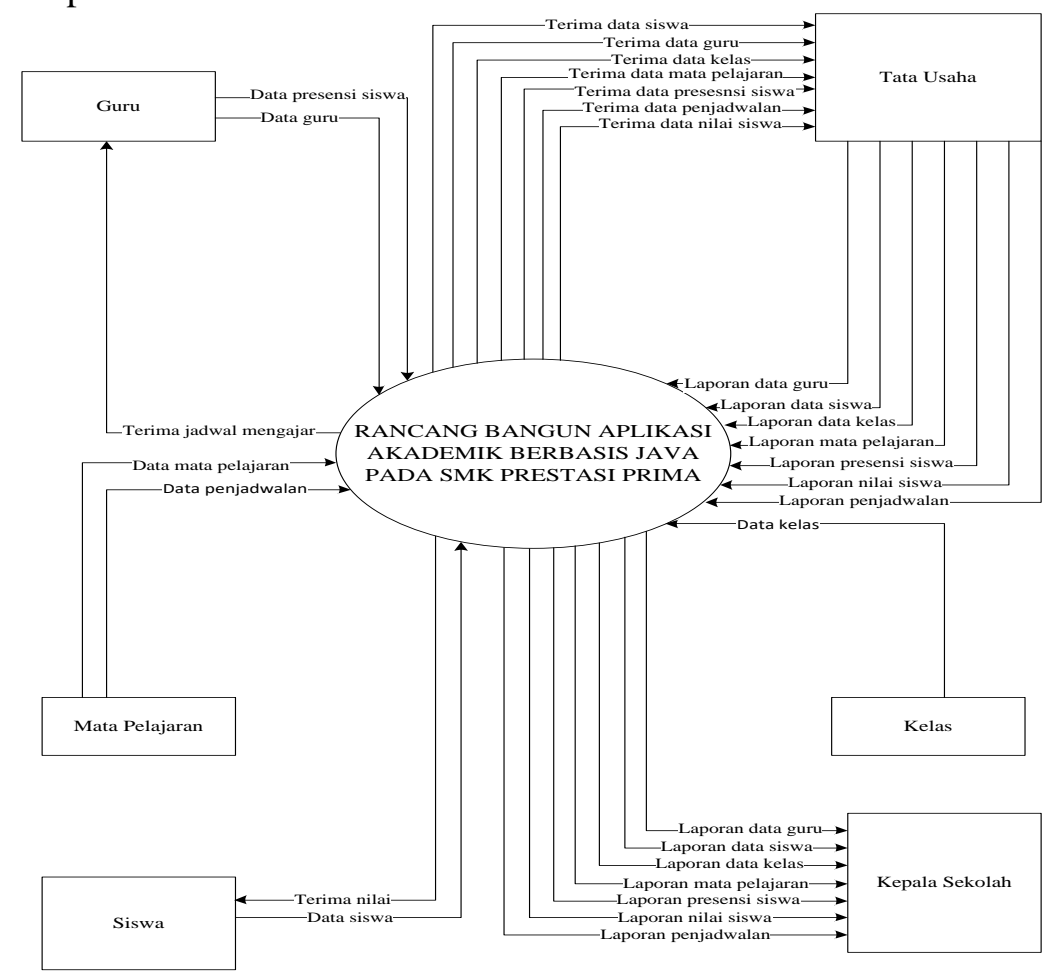

Gambar 1. Diagram Konteks yang Diusulkan 


\section{Diagram Nol yang Diusulkan}

Pada gambar diagram nol yang diusulkan dibawah ini memperlihatkan secara detail dari sistem akademik pada SMK Prestasi Prima, yang menggambarkan sistem yang lebih terkomputerisasi. Tata Usaha yang dapat mengelola data siswa, data guru, data mata pelajaran dan data kelas yang otomatis akan masuk ke dalam masing-masing database seperti pada gambar dibawah. Selain itu tata usaha juga bertugas untuk mencetak laporan yang nantinya akan diberikan kepada Kepala Sekolah

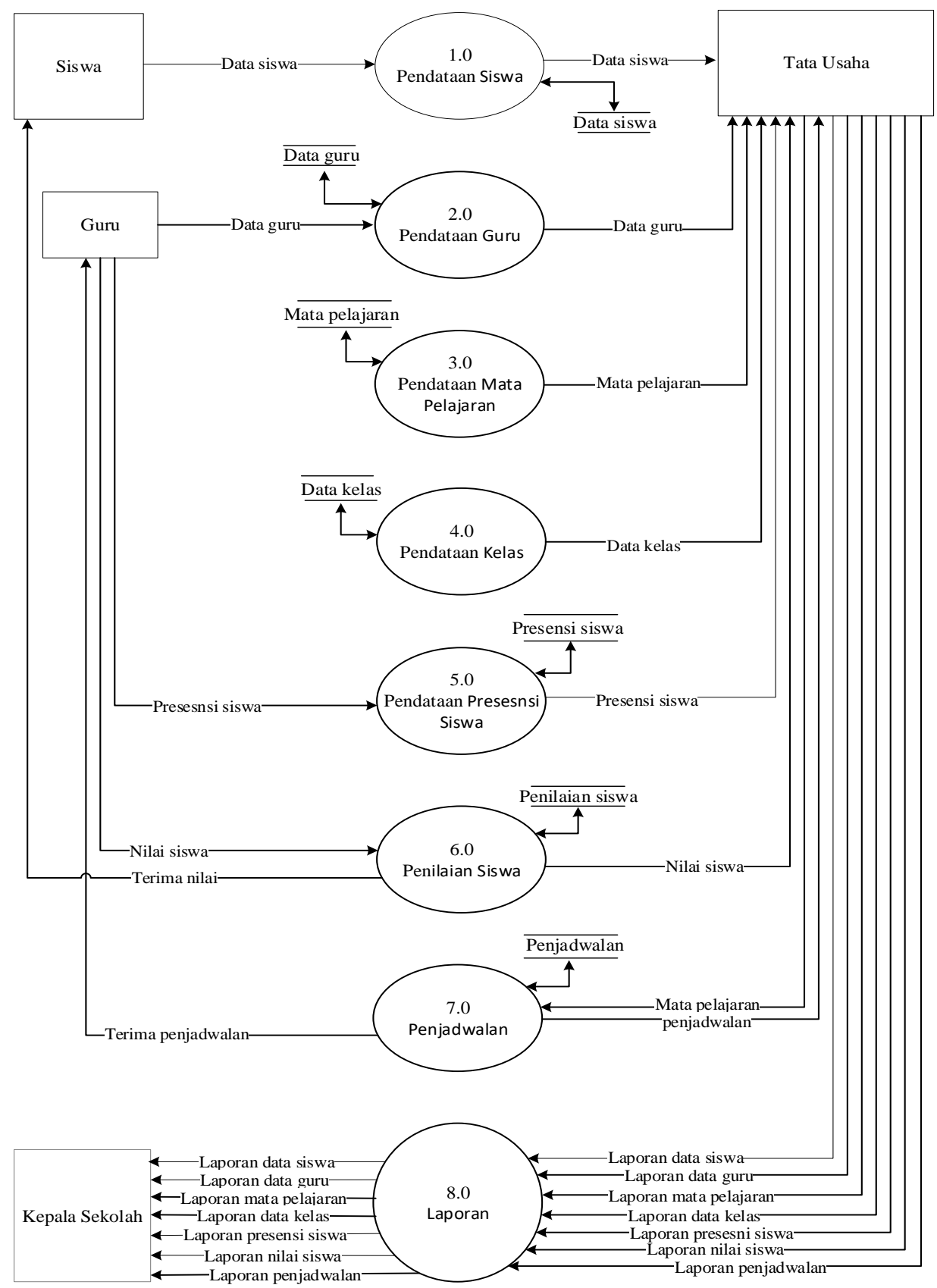

Gambar 2. Diagram Nol yang Diusulkan

\section{Entity Relationship Diagram (ERD)}

Pada gambar Entity Diagram Relationship (ERD) dibawah ini menjelaskan bagaimana alur-alur dalam setiap entitas dan relasi yang berhubungan dengan satu sama lain, dimana setiap siswa akan mengikuti mata pelajaran, mendapat kelas dan mendapat nilai yang diberikan oleh guru sesuai dengan mata pelajaran, lalu guru mendapatkan jadwal mengajar sehingga memberikan presensi siswa yang hadir dalam setiap pelajaran 


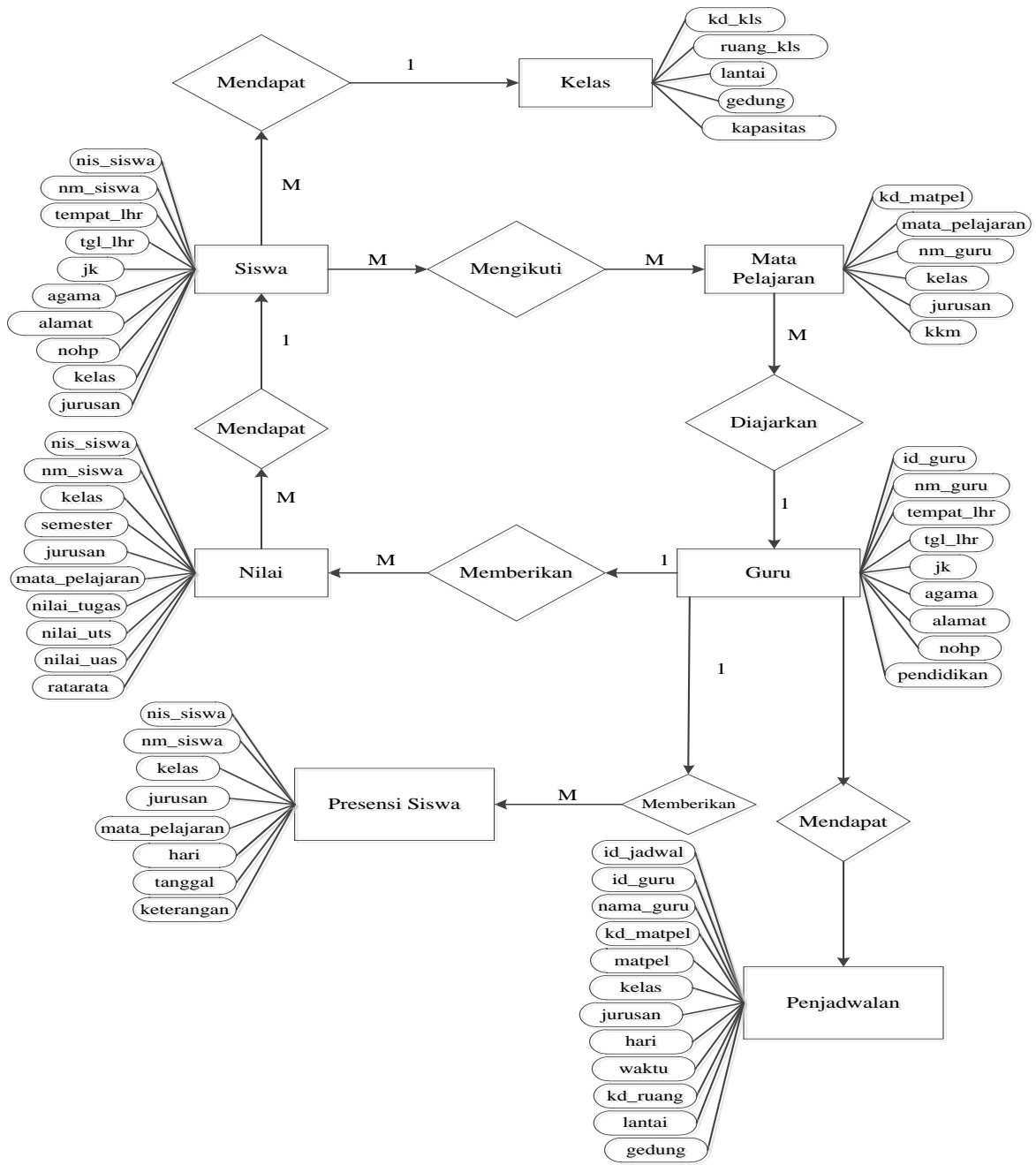

Gambar 3. Entity Diagram Relationship (ERD)

\section{Tampilan Layar}

\section{WELCOME TO}

SMK PRESTASI PRIMA

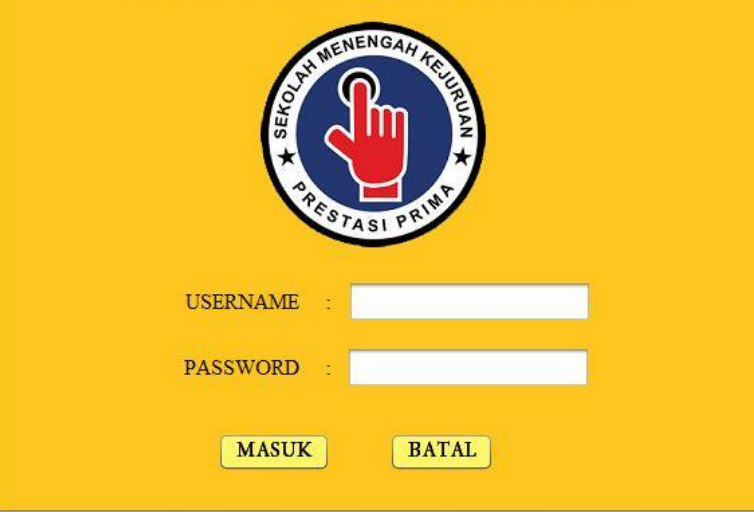

Gambar 4. Tampilan Halaman Login

Tampilan halaman login pada aplikasi akademik ini merupakan akses pertama kali saat aplikasi dijalankan, yang dapat di akses oleh bagian tata usaha sekolah. Untuk masuk ke dalam halaman selanjutnya Tata Usaha harus memasukan Username dan Password sesuai dengan aturan yang ada. 


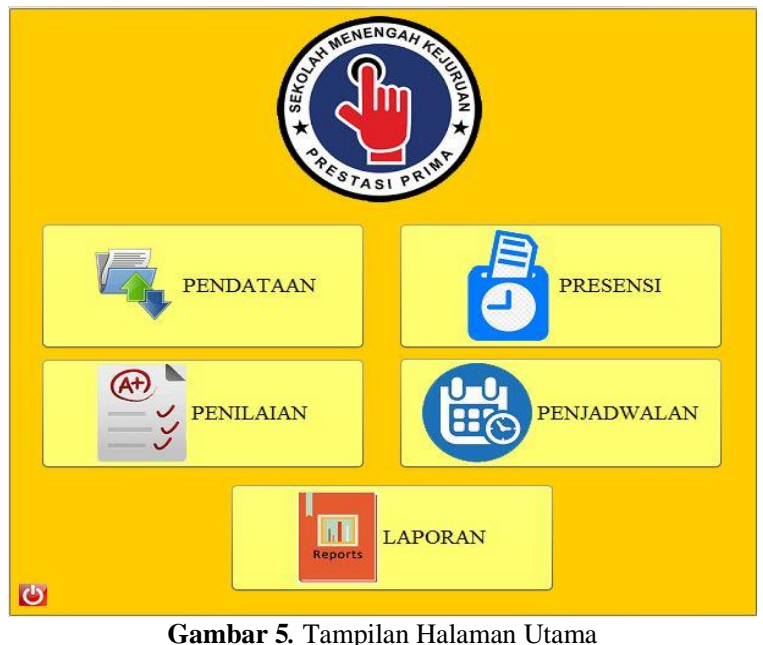

Tampilan halaman utama pada aplikasi akademik merupakan tampilan yang akan muncul setelah masuk dari halaman login, pada halaman utama terdapat menu-menu yang dapat di akses oleh Tata Usaha untuk melakukan penginputan antara lain pendataan, presensi, penilaian, penjadwalan dan laporan.

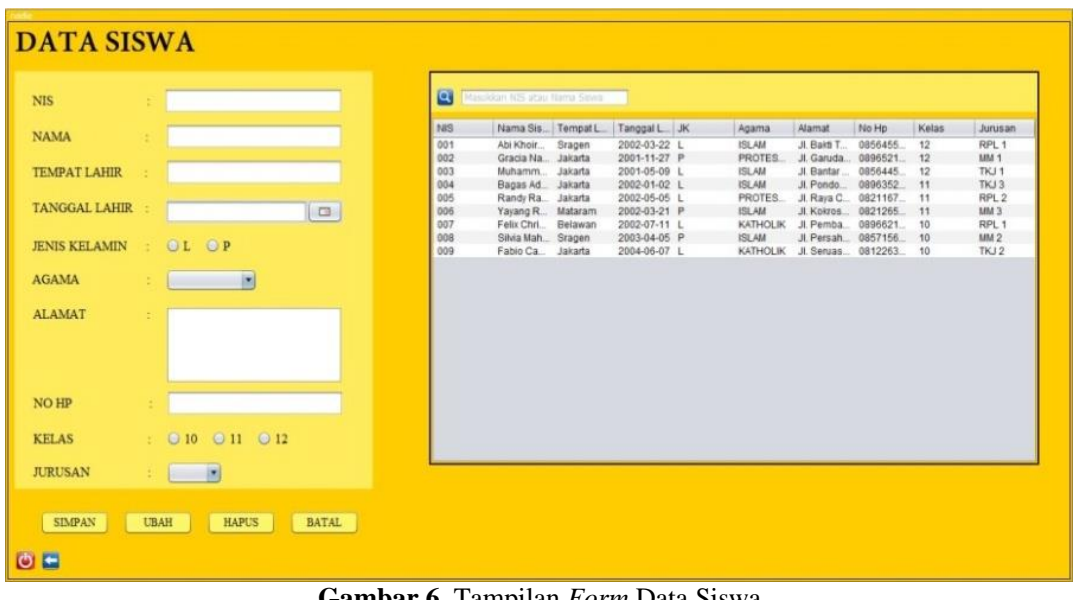

Gambar 6. Tampilan Form Data Siswa

Tampilan form data siswa merupakan salah satu dari proses pendataan yang akan di isi oleh bagian Tata Usaha sekolah terdapat sepuluh field yang harus diisi oleh Tata Usaha, setelah semua di isi data disimpan kedalam database data siswa yang secara otomatis selanjutnya data akan muncul pada tabel yang sudah di sediakan, pada tampilan form data siswa terdapat 6 button anatara lain button simpan, ubah, hapus dan batal yang setiap button mempunyai fungsinya masing-masing.

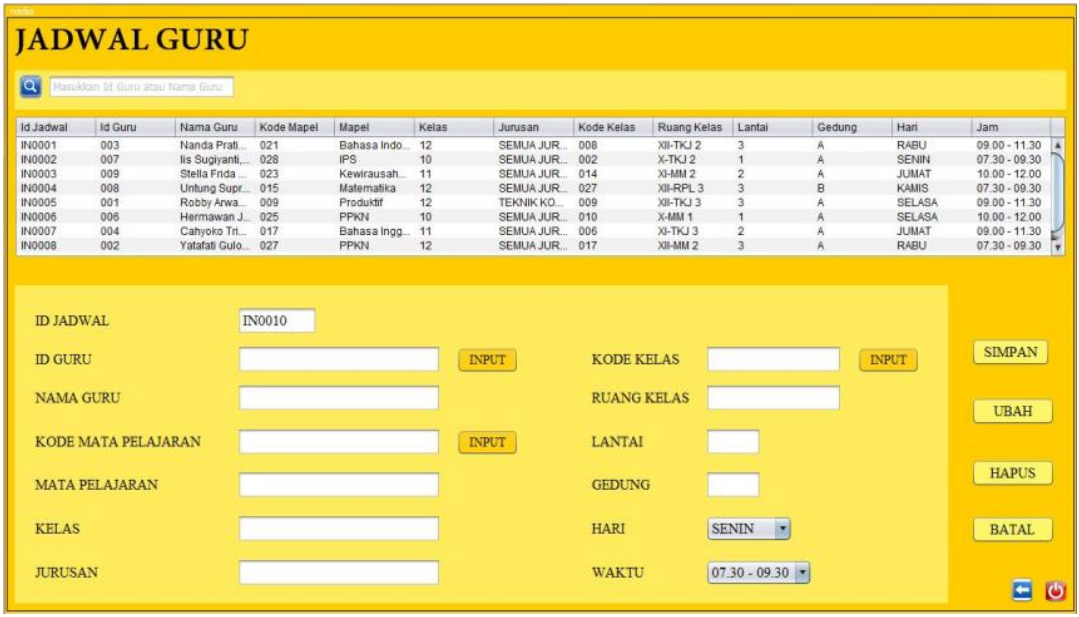

Gambar 7. Tampilan Form Data Jadwal Guru 
Tampilan form data jadwal mengajar guru merupakan proses transaksi pada aplikasi akademik ini, terdapat tiga belas field yang harus diisi oleh bagian Tata Usaha lalu disimpan kedalam database jadwal guru yang selanjutnya secara otomatis akan muncul pada tabel yang sudah disediakan. Pada form jadwal guru terdapat 6 button antara lain button simpan, ubah, hapus dan batal yang mempunyai fungsinya masing-masing.

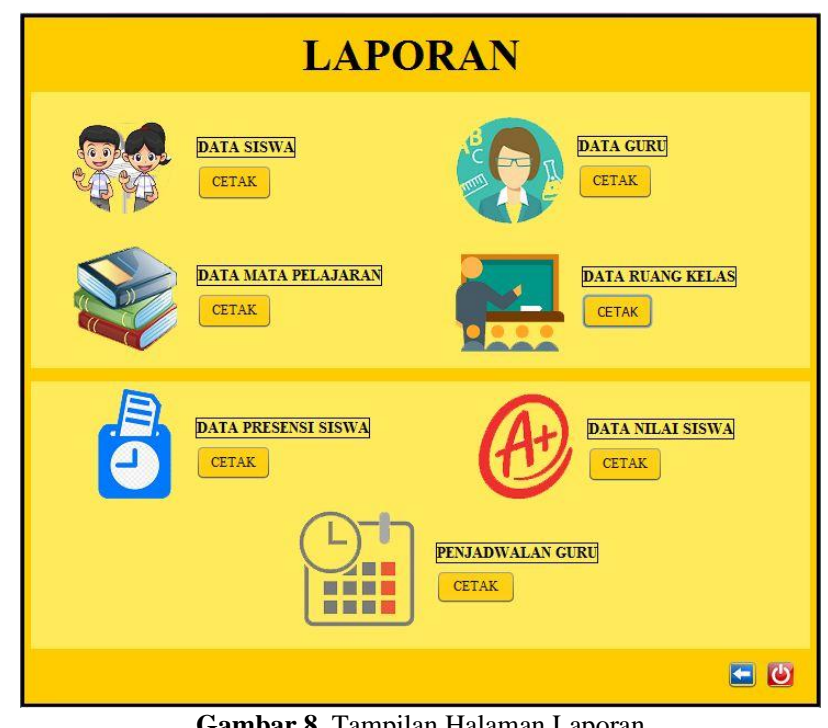

Pada tampilan halaman laporan terdapat 7 button laporan antara lain laporan data siswa, data guru, data mata pelajaran, data ruang kelas, data presensi siswa, data nilai siswa dan data penjadwalan guru. Tata usaha akan melakukan proses pencetakan dengan menekan button cetak pada halaman laporan tersebut untuk diberikan kepada Kepala Sekolah sebagai laporan akademik pada SMK Prestasi Prima.

\begin{tabular}{|c|c|c|c|c|c|c|c|c|c|}
\hline & \multicolumn{9}{|c|}{ 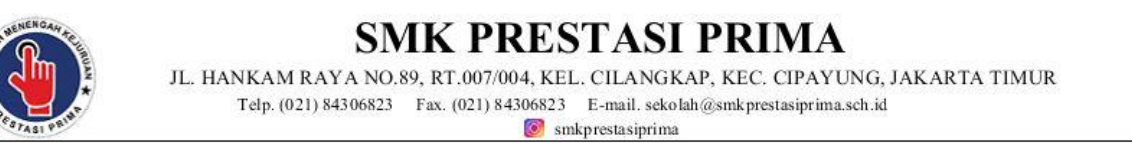 } \\
\hline \multicolumn{10}{|c|}{ DATA SISWA } \\
\hline NIS & Nama Siswa & Tempat Lathir & Tang gal Lahir & \begin{tabular}{|l|} 
Jenis Kelamin \\
\end{tabular} & Agama & Abmat & NoHP & Kelas & Junsuan \\
\hline 001 & Abi Khoirumudien All Fath & Stragen & $2002-03-22$ & L & ISLAM & \begin{tabular}{|l|l} 
Jl. Bakti Tapos, Depook \\
\end{tabular} & \begin{tabular}{|l|}
085645577102 \\
\end{tabular} & 12 & RPL 1 \\
\hline 002 & Gracia Natalia Mardena & Jakata & $2001-11-27$ & $\mathrm{P}$ & PROTESTAN & \begin{tabular}{|l|l} 
JI. Garvda Kelapa Dua, Depok \\
\end{tabular} & \begin{tabular}{|l|}
099652111019 \\
\end{tabular} & 12 & MM 1 \\
\hline 003 & Muhammad Widan & Jakarta & $2001-05-09$ & $\mathrm{~L}$ & ISLAM & Jl. Bantar Jaf Cipayurg, Jakarta & 085644503353 & 12 & TKJ 1 \\
\hline 004 & Bagas Aditya Sattio & Jakarta & $2002-01-02$ & L & ISLAM & \begin{tabular}{|l|l|} 
JI. Pondok Gede Bekasi \\
\end{tabular} & \begin{tabular}{|l|}
089635266372 \\
\end{tabular} & 11 & TKJ 3 \\
\hline 005 & Randy Raditya & Jakatta & $2002-05-05$ & L & PROTESTAN & \begin{tabular}{|l|l} 
J1. Raya Ciracas Jakarata Timur \\
\end{tabular} & 082116770023 & 11 & RPL2 \\
\hline 006 & Yayang Rengganis & Mataram & $2002-03-21$ & $\mathrm{P}$ & ISLAM & \begin{tabular}{|l|l|} 
JI. Kokrosono Halim, Jakarta \\
\end{tabular} & \begin{tabular}{|l|}
082126569015 \\
\end{tabular} & 11 & МM 3 \\
\hline 007 & Felix Chrixtian Rajaguguk & Belawan & $2002-07-11$ & L & KATHOLIK & \begin{tabular}{|l|l|} 
Jl. Pembangunan Kelapa Dua \\
\end{tabular} & 089662111982 & 10 & RPL 1 \\
\hline 008 & Silvia Maharani & Sragen & $2003-04-05$ & $P$ & ISLAM & \begin{tabular}{|l|l|} 
Jl. Persahabatan Kelapa Dua \\
\end{tabular} & \begin{tabular}{|l|}
08571567780 \\
\end{tabular} & 10 & MM 2 \\
\hline 009 & Fabio Cannavaro & Jakarta & 2004-06-07 & $\mathrm{L}$ & KATHOLIK & Ju. Seruas Pondok Melati, Bekasi & Q81226337654 & 10 & TKJ 2 \\
\hline & & & & & & & \multicolumn{3}{|c|}{$\begin{array}{l}\text { Jakanta, Jumat } 19 \text { Juni } 2020 \\
\text { Mengetahui } \\
\text { Kepala Sekolah SMK Prestasi Prima }\end{array}$} \\
\hline & & & & & & & \multicolumn{3}{|c|}{ David H.Silaen S.T., M.Pd } \\
\hline
\end{tabular}

Gambar 9. Tampilan Laporan Data Siswa

Tampilan laporan data siswa diatas tata usaha dapat langsung mencetak data siswa secara keseluruhan dan dapat diubah isi dari form data siswa bila terjadi kesalahan. Jika sudah dicetak laporan dapat diberikan kepada Kepala Sekolah untuk dicek kembali dan sebagai laporan dalam kegiatan akademik SMK Prestasi Prima. 


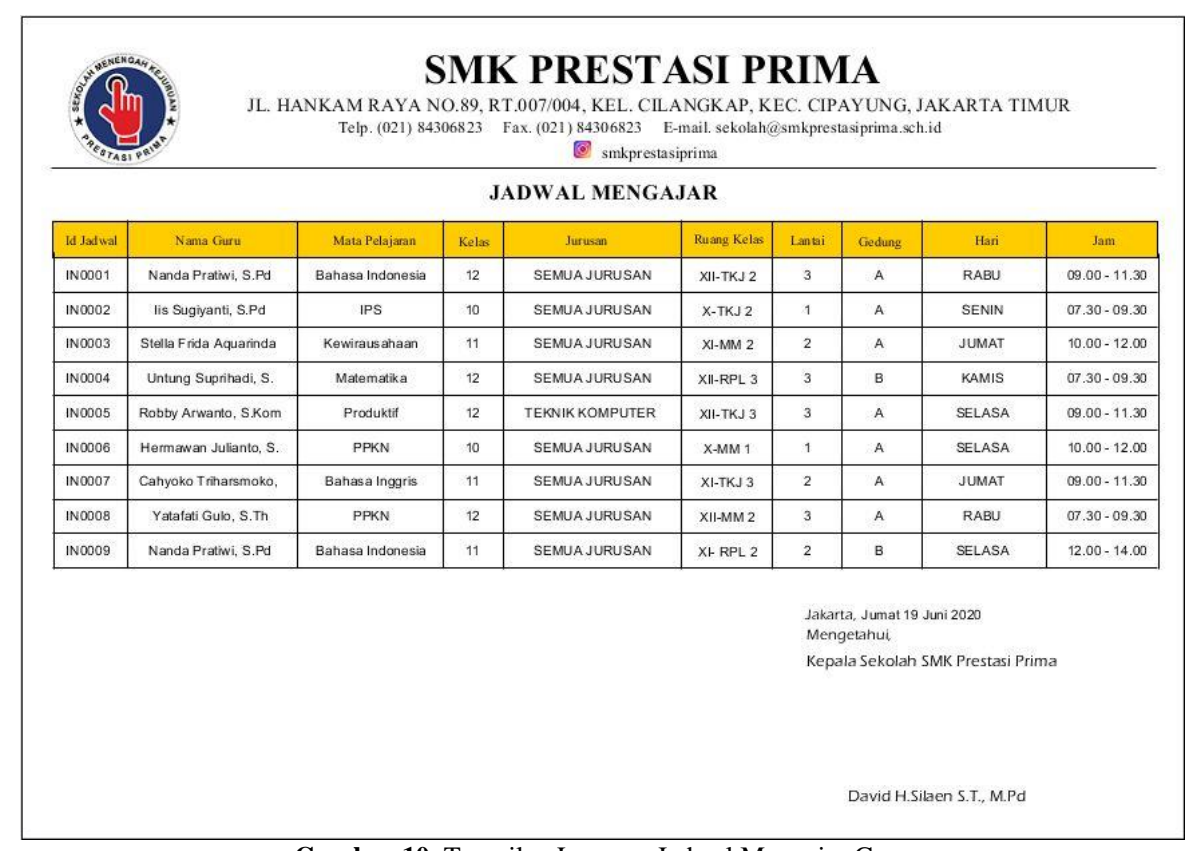

Gambar 10. Tampilan Laporan Jadwal Mengajar Guru

Tampilan laporan data jadwal menagajar diatas tata usaha dapat langsung mencetak data jadwal mengajar secara keseluruhan dan dapat diubah isi dari form data jadwal mengajar bila terjadi kesalahan. Jika sudah dicetak laporan dapat diberikan kepada masing-masing guru sebagai jadwal mengajar setiap guru dan kepada Kepala Sekolah untuk dicek kembali dan sebagai laporan dalam kegiatan akademik SMK Prestasi Prima.

\section{SIMPULAN}

Hasil penjelasan mengenai aplikasi akademik pada SMK Prestasi Prima dapat terlihat bahwa penggunaan komputer semaksimal mungkin dapat membantu pekerjaan tata usaha dalam melakukan pendataan, pencatatan ataupun laporan yang sifatnya berulang-ulang. Dengan adanya sistem yang telah terkomputerisasi akan mendapatkan beberapa kesimpulan, adalah dengan dibuatnya sistem baru yang dirancang menggunakan bahasa pemrograman Java Netbeans IDE, dengan menggunakan Database MySQL. Pihak tata usaha akan lebih efektif dan efisien dalam bentuk biaya dan waktu dalam mengolah pendataan dan melakukan pencarian data. Komputerisasi sebagai pemecah masalah dalam menangani masalah-masalah yang terdapat pada sistem akademik yang sedang berjalan saat ini diharapkan dapat membantu dan merupakan salah satu alternatif pemecahan masalah, sehingga proses akademik pada SMK Prestasi Prima yang ada lebih terkontrol dengan sistem komputerisasi ini.

\section{DAFTAR PUSTAKA}

Anggraeni, E. Y., \& Irviani, R. (2017). Pengantar Sistem Informa. Cv. Andi Offset.

Ilham. (2019). NetBeans IDE. Features.

Jeperson, H. (2014). Konsep Sistem Informasi. Jurnal Administrasi Pendidikan UPI.

Jogiyanto. (2010). Analisa dan Desain Sistem Informasi. Yogyakarta: Andi, 3(4), 57-62.

Kuryanti, S. J. (2014). Perancangan Sistem Informasi Akademik Sekolah Berbasis Web Dengan Java. Jurnal Khatulistiwa Informatika, 2(1), 77-86.

Nofriadi. (2015). Java Fundamental Dengan Netbeans 8.0.2. DeePublish.

Setiawan, A., Lina, I. M., \& Parwatiningtyas, D. (2020). Sistem Informasi Administrasi Kegiatan (Event) Di Perusahaan CRPG Menggunakan Java. Jurnal Riset Dan Aplikasi Mahasiswa Informatika (JRAMI), 1(3). https://doi.org/10.30998/jrami.v1i03.383

Shiddiq, S., \& Pradnya D, W. M. (2013). Sistem Informasi Akademik Dan Administrasi Sdit Ar-Raihan Bantul. Data Manajemen Dan Teknologi Informasi (DASI), 14(4), 49.

Sugiarti, Y. (2013). Analisis \& Perancangan UML (Unified Modeling Language) Generated VB.6. Graha Ilmu. https://doi.org/http://dx.doi.org/10.1109/ICCSN.2010.19

Sutabri, T. (2012). Analisis Sistem Informasi. Analisa Sistem Informasi. 